\title{
Reply to Letter to Editor: Safety of one-stage bilateral total knee arthroplasty-one-surgeon sequential vs. two surgeons simultaneous: a randomized controlled study
}

\author{
Gökçer Uzer $^{1} \cdot$ Orkhan Aliyev $^{1}$ (D) $\cdot$ Fatih Yıldız $^{1}$ (D) Nurdan Güngören ${ }^{1}$ (D) $\cdot$ Nurzat Elmalı $^{1} \cdot$ Ibrahim Tuncay $^{1}$
}

Received: 17 August 2020 / Accepted: 21 August 2020 / Published online: 26 August 2020

(C) SICOT aisbl 2020

We would like to thank to Dr. Shigemura and his colleagues from Japan, Chiba for their time in expressing their concerns and interest in our article entitled "Safety of one-stage bilateral total knee arthroplasty -one surgeon sequential vs. two surgeons simultaneous: a randomized controlled study." In our prospective randomized study, we showed that one-stage bilateral total knee arthroplasty (TKA) with two surgeons (simultaneous) is safer than one-surgeon bilateral TKA (sequential) in terms of early post-operative complications [1]. In addition to lower complication rates, we found that simultaneous-bilateral TKA decreases operative time significantly but increases the total amount of blood loss.

There is no doubt that achieving good component alignment in the three planes is of great importance in terms of long-term outcomes of the knee prosthesis. In his letter to the editor, Dr. Shigemura emphasizes this point and notes potential concerns with the radiological results in these methods [2]. We agree that the alignment of the components after total knee arthroplasty is an important prognostic factor for wear and affects patient satisfaction [3-5]. Although two-surgeon bilateral TKA is thought to be disadvantageous in accurate prosthesis implantation by Dr. Shigemura, we did not observe difficulties in using soft tissue retractors bilaterally at the same time, and they rarely interfered with each other and did not cause an inadequate operative field. We think that experience of the surgical team, the assistants, and the nurses are very important to prevent surgical equipment interference and provide adequate working area and surgical field. We agree that alignments of the prostheses and the lower extremity may not be radiologically identical at both sides. Moreover, there is possibility of anatomical variations between the right and

Fatih Y1ldiz

yildizfatih@hotmail.com

1 Department of Orthopaedics and Traumatology, Bezmialem Vakıf University, Istanbul, Turkey left knees, which may cause differences in the component alignments and their sizes. In our series, in a simultaneous bilateral TKA group, each surgeon decided independently in terms of component positioning and their sizes.

As Dr. Shigemura, we thought this issue to be important, and concerns with radiologic results in simultaneous bilateral TKA with two surgeons may limit the generalizability of this method. To our knowledge, there is no article in the literature that compares radiological results of these two methods. For this reason, in our other unpublished prospective study (http://clinicaltrials. gov/, NCT04434690), we compared the mid-term radiological results of patients who were included in the published study and completed a 24-month follow-up, and we found that one-surgeon sequential bilateral TKA and two-surgeon, simultaneous bilateral TKA provides similar radiological outcomes.

\section{References}

1. Uzer G, Aliyev O, Yildiz F, Gungoren N, Elmali N, Tuncay I (2020) Safety of one-stage bilateral total knee arthroplasty -one surgeon sequential vs. two surgeons simultaneous: a randomized controlled study. Int Orthop. https://doi.org/10.1007/s00264-020-04704-9

2. Shigemura T, Yamamoto Y, Wada Y (2020) Letter to the editor regarding "Safety of one-stage bilateral total knee arthroplasty -one surgeon sequential vs. two surgeons simultaneous: a randomized controlled study". Int Orthop. https://doi.org/10.1007/s00264-02004744-1

3. Fang DM, Ritter MA, Davis KE (2009) Coronal alignment in total knee arthroplasty: just how important is it? J Arthroplast 24:39-43. https://doi.org/10.1016/j.arth.2009.04.034

4. Collier MB, Engh CA Jr, McAuley JP, Engh GA (2007) Factors associated with the loss of thickness of polyethylene tibial bearings after knee arthroplasty. J Bone Joint Surg Am 89:1306-1314. https:// doi.org/10.2106/JBJS.F.00667

5. Jeffery RSMR, Denham RA (1991) Coronal alignment after total knee replacement. J Bone Joint Surg (Br) 73(5):709-714

Publisher's note Springer Nature remains neutral with regard to jurisdictional claims in published maps and institutional affiliations. 